\title{
The Impact of Strategies Human Resource Management on Organizational Commitment. (An Applied Study on Employees in Jordanian Islamic Banks)
}

\author{
Mohammad. A. O. Almutairi ${ }^{1} \&$ Dr: Ayyoub. A. Alsawalhah ${ }^{2}$ \\ ${ }^{1}$ Researcher, PhD student, The word Islamic Science and education university - Jordan \\ ${ }^{2}$ Faculty of Business and Finance, World Islamic Sciences and Education University, Jordan \\ Correspondence: Dr: Ayyoub. A. Alsawalhah, Faculty of Business and Finance, World Islamic Sciences and \\ Education University, Jordan
}

Received: February 9, 2020

Accepted: March 5, 2020

Online Published: March 7, 2020

doi:10.5539/mas.v14n4p14

URL: https://doi.org/10.5539/mas.v14n4p14

\begin{abstract}
The present study aimed to explore the impact of strategies human resource management (SHRM) (recruitment, training, compensation, and performance management) on organizational commitment, An applied study on employees in Jordanian Islamic banks. It was found that the strategies human resources management in Jordanian Islamic banks is high. It was found that the employees' organizational commitment level in Jordanian Islamic banks is high. There is a statistically significant effect at the level $(\alpha \leq 0.05)$ of strategies human resource management (employment, training, compensation and performance management) on organizational commitment (respect for values and ethics, willingness to commit to work, creative behavior at work), an applied study on employees in Jordanian Islamic banks. The researchers recommend: developing the strategies of the human resources management in a manner that is consistent with the external environment of the organization.
\end{abstract}

Keywords: strategies human resources management, organizational commitment, Jordanian Islamic banks

\section{Introduction}

Achieving organizational success requires having employees who have a high organizational commitment level. Having a high organizational commitment level shall make the employee willing to meet the organization's goals. It shall make the employee interested in remaining at the organization. It shall make the employee keen to preserve the organizational resources. The success of any organization is not affected only by the development of its human resources' capabilities. In fact, it is also affected by the way in which the management encourages its employees to show organizational commitment. It is also affected by the way in which the management integrates the employees in the organizational environment. Through such integration, the bonds between the employees and the organization shall become stronger (Alraggad, 2017).

Researchers realize that human resources management has become strategic since 1990s. In the light of this change, several terms have been receiving attention, such as: the distinguished employee, strategic partner, and leader of change (Ulrich, 1997). Human resources in organizations play a vital role. For instance, they enable organizations to survive in the business environment. The organization's life cycle begins when the organization is created and ends when the organization leaves the market. Therefore, a comprehensive strategy must be developed for managing human resources. That is needed in organizations for having an effective organizational management (Alsawalhah, 2015, Alsawalhah, 2013 \& khashman el at., 2009). strategies human resources management are needed to develop and implement a set of policies and practices (Baird and Meshoulam, 1988). They aim at achieving a competitive advantage and improving the organizational performance. The latter performance has been receiving much attention by researchers and businessmen. In this regard, it should be noted that many researchers found that there is a significant relationship between strategies human resources management and organizational performance. It should be noted that are many studies published about the latter strategies (Wright \& Gardner, 2003).

Strategies human resource management (SHRM) play an important role in building organizational commitment, it provides human resources that are compatible with the organizational culture, and able to adapt to the requirements of the work environment. 


\section{The Study's Objectives}

- Define strategies human resource management that are applied in Jordanian Islamic banks.

- Define the level of organizational commitment in Jordanian Islamic banks.

- Identify the impact of strategies human resource management on organizational commitment in Jordanian Islamic banks.

\section{Statement of the Problem and the Study's Questions}

Similar to other banks, Islamic banks are highly concerned in raising employees' organizational commitment.. That is needed in the light of having a very competitive market. Organizations must adapt themselves with the competitive environment in a constant manner. Many researchers suggested that there is a relationship between organizational commitment from one hand, and employee loyalty, employee retention, employee turnover and extent of meeting the employees' expectation from another hand in Islamic banks.

\section{The Study's Questions}

the main Question : What is the impact of strategies human resources management (recruitment, training, compensation, and performance management) on organizational commitment of Jordanian Islamic banks from .

\section{The following Questions are derived from the main Question:}

- What is the impact recruitment on organizational commitment of Jordanian Islamic banks.

- What is the impact of training on organizational commitment of Jordanian Islamic banks.

- What is the impact of compensation on organizational commitment of Jordanian Islamic banks.

- What is the impact of performance management on organizational commitment of Jordanian Islamic banks.

\section{The Study's Hypotheses}

Based on the problem of the study and its question, the following hypotheses have been formulated:

main hypothesis H0.1: There is no significant impact at $(\alpha \leq 0.05)$ level of the strategies human resource management (employment, training, compensation, and performance management) on organizational commitment of Jordanian Islamic banks.

\section{The following hypotheses are derived from the main hypothesis:}

H0.1.1: There is no significant impact at $(\alpha \leq 0.05)$ level of the strategies human resource management (employment) on organizational commitment of Jordanian Islamic banks.

H0.1.2: There is no significant impact at $(\alpha \leq 0.05)$ level of the strategies human resource management (training) on organizational commitment of Jordanian Islamic banks.

H0.1.3: There is no significant impact at $(\alpha \leq 0.05)$ level of the strategies human resource management (compensation) on organizational commitment of Jordanian Islamic banks.

H0.1.4: There is no significant impact at $(\alpha \leq 0.05)$ level of the strategies human resource management (performance management) on organizational commitment of Jordanian Islamic banks.

\section{Previous Literature}

\subsection{Strategies Human Resource Management (SHRM)}

Strategic management and human resources have been receiving much attention. The researchers who are concerned in human resources management have shifted their attention from individual's effectiveness to organizational effectiveness and strategic approaches. When shedding a light on human resources management from a strategic point of view, it can be clear that human resources management practices can significantly affect the organizational performance. For instance, the latter practices can significantly affect financial performance, productivity, employee succession, work load, and employee turnover And on organizational commitment (Shawabkeh, Alsawalhah, 2019).

The term (strategic human resources management) emerged due to the significance of human resources management. For instance, the latter management aims at meeting the strategic goals of the organization. Meeting such goals is highly needed to improve the organizational performance, increase creativity, develop the organizational culture and show a higher level of responsiveness (Assaf, 2017). Strategic human resources management involves a set of strategies that aim at having processes carried out skillfully by employees. These 
strategies aim at raising employees' commitment level. They aim at providing employees with motives to meet the organizational goals. They aim at developing employees' capability to adapt themselves with the business environment that is characterized with being competitive, changing and complex (Sarker \& Rahman, 2018).

\section{The dimensions of strategies human resources management:}

strategies human resources management involve a set of decisions and procedures that are related to the management of employees of various organizational levels. They involve implementing strategies that aim at achieving development and a competitive advantage. There are several types of strategies human resources management, such as: the strategies of (recruitment, training, compensation, and performance management) (Foot and Hook, 2009).

\section{First: Recruitment:}

Recruitment involves the attraction of qualified candidates for jobs in an organization. It also involves selecting and appointing the ones who are qualified for jobs. The recruitment decision is made based on the extent of meeting a set of criteria by the concerned candidate.( (Foot and Hook, 2009)

\section{Second: Training:}

Training is one of the important elements of the human resources management. It aims at providing employees with the required knowledge, skills, and attitudes for improving their performance at work. It involves several activities that aim at providing employees with new knowledge, and skills that shall enable them to achieve personal development. It shall affect the organizational performance because it aims at developing employees' skills, capabilities and knowledge in an ongoing manner. It should be noted that there is a significant relationship between training and development from one hand and organizational performance from another hand(Foot and Hook, 2009).

\section{Third: Compensations}

Compensations management is one of the important elements of the human resources management (Onwuka, Onwuchekwa,2018 ). It aims at attracting the best employees and making the organizational environment a very preferred work environment by the employees. The compensations management program aims at providing the employees with offers that are better than their competitors' offers, in terms of overtime, pay scale, payment strategies, and job rotation. The compensation management strategy is one of the components of human resource strategies. They involve strategies related to salaries, wages, \& incentives, and the way of paying them. They involve strategies related to the adjustments made to salaries, wages, \& incentives in the light of factors related to the environment (Onwuka, Onwuchekwa,2018). They can significantly affect the extent of motivating the employees. They play a significant role in meeting the organizational goals (Adeoye, 2014). They play a significant role in attracting the candidates of a job. They affect the employees' desire to work hard. Thus, they affect the organizational productivity, organizational stability and extent of meeting the organizational long term goals.

\section{Fourth: Performance management:}

Performance management strategies are strategies human resources management. They significantly affect the organizational performance and excellence. They aim at enforcing control over the employees' productivity in accordance with specific standards. They enable the organization to identify the extent of the employee's contribution in carrying out the organizational activities and meeting the organizational goals. The outcomes of the employee's works must meet several pre-established standards in order to achieve a competitive advantage (Foot and Hook, 2009)

\subsection{Organizational Commitment}

Organizational commitment emerged at the beginning in the field of industrial-organizational psychology (Cohen, 2007): The early studies about organizational commitment shed a light on this concept through exploring individuals' attitudes towards it. This concept involves: identity, collaboration and loyalty (Porter, Steers, and Mowday, 1979). In this context, attitude refers to one's psychological tendencies or emotional commitment that the employee forms. Organizational commitment refers to the employee's attachment to the organization and intention to keep working at it. It involves the employee's desire to identify the values and goals of the organization. It involves the employee's desire to exert additional effort for the favor of the organization. Meyer and Allen (1984) suggest that the term (organizational commitment) involves 3 types of commitment; affective, normative and continuous commitment. Meyer and Allen (1984: 375) suggest that affective commitment refers to positive feelings that result from being attached to the organization and engaging 
in its activities. They add that continuous commitment refers to the employee's sense of commitment to the organization he/she works at due to the fear of loss. They add that normative commitment refers to the employee's sense of obligation to stay in the organization. Hence, the expression (organizational commitment) is a three dimensions expression (Meyer and Allen, 1984).

\section{Dimensions of organizational commitment}

\section{Creative behavior at work (affective commitment)}

Affective commitment refers to the employee's emotional desire to keep working at the organization, because the organization enables them to realize themselves. The nature of the relationship between the employee and the organization significantly affects the extent of the employee's dedication and loyalty. Having a high organizational commitment level requires having an emotional attachment within the employee towards the organization. It requires engaging the employee in the decision making process and acknowledging his/her value (Qaisar et al., 2012). affective commitment " is a positive attitude toward the organization" (Singh \& Gupta, 2015). Mahal (2012) also noted that an individual's attitude is directly related to whatever personal values they bring to the organization. How individuals identify and involve themselves within an organization exemplifies the relative strength of affective commitment (Faloye, 2014).

\section{Desire to show work commitment (continuous commitment)}

Desire to show work commitment is derived from the employee's continuous commitment. The latter commitment is discussed through the investment theory. When an employee joins a specific organization, he/she is obliged to work at that organization, because there isn't any alternative opportunity. He/she is obliged to work at that organization, because he/she realizes the financial costs associated with leaving the organization (Dixit \& Bhatti 2012). the individual's association with the organization is based on an ongoing assessment of economic benefits gained by remaining with the organization (Faloye, 2014). Organizational members develop commitment because of the positive extrinsic rewards obtained without necessarily identifying with the organization's goals and values (Faloye, 2014).

\section{Compliance with values and ethics (normative commitment)}

Showing Compliance with values and ethics indicates that the employee have a high sense of obligation to stay in the organization. There are employees who have a high level of normative commitment (Assaf, 2013).

Messner (2013) described normative commitment " as the work behavior of individuals, guided by a sense of duty, obligation, and loyalty toward the organization ". Organizational members remain committed based on moral reasons ( Singh \& Gupta, 2015). " The normative committed employee stays in an organization because it is perceived by him or her as morally right to do so, regardless of how much status or satisfaction the organization provides over the years" (Messner, 2013).

\section{Study Data Analysis and Hypothesis Testing}

\subsection{The Study's Methodology and Sample}

Analytical descriptive approach was adopted to analyze the collected data. A questionnaire was used. Through using the questionnaire, personal and occupational data was collected from the respondents. The questionnaire consists from 30 statements that shed a light on the study's variables. The study applied to Islamic banks of Jordan, where a random stratified proportional sample of 135 respondent was chosen. A total of 135 questionnaires were distributed amongst the upper and middle management across Jordanian Islamic banks in Amman . 124 questionnaire forms were retrieved. The response rate is $92 \% .4$ forms are excluded because they aren't considered valid for statistical analysis. Thus, 120 questionnaire forms were analyzed statistically. $88 \%$ of the distributed forms were analyzed. 


\subsection{A Questionnaire Data Analysis}

Table 1. Means and standard deviations about the strategies human resource management and the level of organizational commitment in Jordanian Islamic banks

\begin{tabular}{cccccc}
\hline Items & Variable & Mean & Std. & Percentage & Rank \\
\hline $\mathbf{1 - 5}$ & recruitment & 4.25 & 0.532 & 80.2 & High \\
$\mathbf{1 0 - 6}$ & training & 4.01 & 0.632 & 77 & High \\
$\mathbf{1 5 - 1 1}$ & compensation & 4.02 & 0.892 & 75 & High \\
$\mathbf{2 0 - 1 6}$ & performance & 3.96 & 0.425 & 73.8 & High \\
& management & & & & \\
$\mathbf{2 0 - 1}$ & strategies human & & & & High \\
& resources & 4.06 & & 78.2 & High \\
& management & & & & \\
$\mathbf{1 0 - 1}$ & Organizational & 3.94 & & & \\
& commitment & & & & \\
\hline
\end{tabular}

\section{Based on table (1), the following information can be concluded:}

The independent variable: The strategies human resources management: The overall mean of the strategies human resources management is 4.06 which is high. It is represented by a percentage of $81.2 \%$. Thus, the strategies human resources management in Jordanian Islamic banks is high. The dependent variable: Organizational commitment: The mean of the employee's organizational commitment is 3.94 which is high. That means that the employees' organizational commitment level in Jordanian Islamic banks is high

\subsection{Testing the Study's Hypotheses}

The following table (2) presents the results of testing the first main hypothesis.

H0.1: There is no significant impact at $(\alpha \leq 0.05)$ level of the strategies human resource management (employment, training, compensation, and performance management) on organizational commitment of Jordanian Islamic banks.

Table 2. Multiple Regressions for the First Main Hypothesis

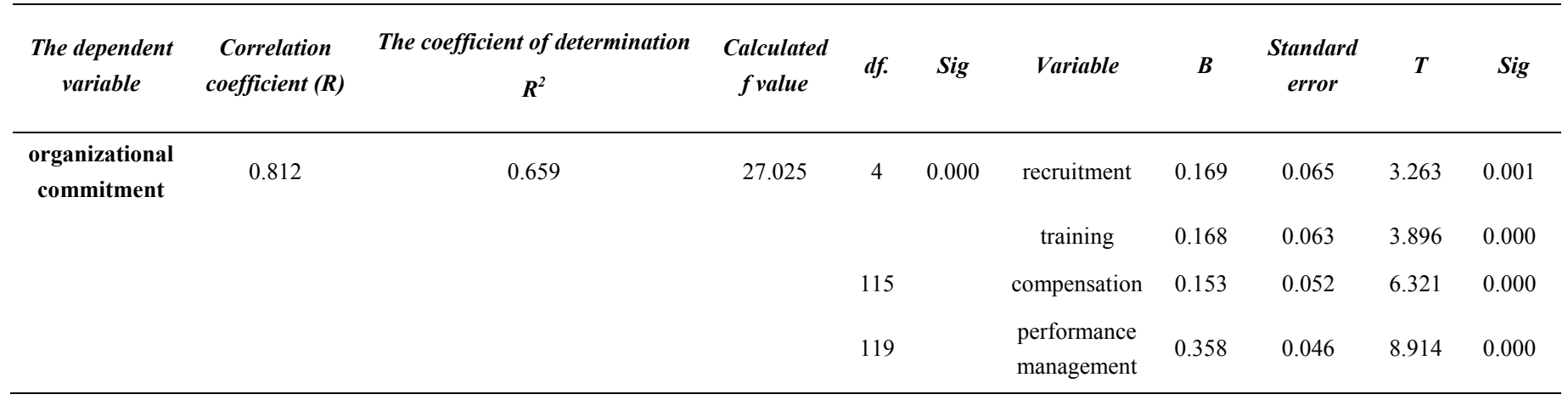

$(*)$ : This sign means that the value is statistically significant impact -at the statistical significance level of $a \leq 0.0$

Based on table (2), it can be concluded that the strategies human resources management has a significant impact on organizational commitment. The correlation coefficient $(\mathrm{R})$ value is $=(0.812)$. That means that there is a significant positive relationship between the independent and dependent variables. In addition, it was found that the independent variable has a significant impact on the dependent variable. That means that the strategies human resources management has a significant impact on organizational commitment. That is because the calculated $\mathrm{F}$ value is 27.025 and the significance value is 0.000 . The latter value is less than 0.05 . It was found that the coefficient of determination $\mathrm{R}^{2}$ is 0.659 . That means that 65.9 of the variation in the organizational commitment jointly can be attributed to the strategies human resources management jointly. Based on the aforementioned information, the main hypothesis is rejected. There is significant impact at $(\alpha \leq 0.05)$ level of the strategies human resource management (employment, training, compensation, and performance management) on 
organizational commitment of Jordanian Islamic banks.

\section{The results of testing the sub-hypotheses are presented below}

H0.1.1: There is no significant impact at $(\alpha \leq 0.05)$ level of the strategies human resource management (employment) on organizational commitment of Jordanian Islamic banks.

Table 3. The impact of the recruitment strategies on the employees' organizational commitment in Jordanian Islamic banks

\begin{tabular}{|c|c|c|c|c|c|c|c|c|c|}
\hline $\begin{array}{c}\text { Correlation } \\
\text { coefficient } \\
\text { (R) }\end{array}$ & $\begin{array}{c}\text { The coefficient of } \\
\text { determination } R^{2}\end{array}$ & $\begin{array}{c}\text { Calculated } f \\
\text { value }\end{array}$ & Result & $d f$. & $\begin{array}{l}\text { Regression } \\
\text { coefficient }\end{array}$ & & & & \\
\hline & & & & & $\begin{array}{c}\text { Independent } \\
\text { variable }\end{array}$ & $\beta$ & $\begin{array}{c}\text { standard } \\
\text { error }\end{array}$ & $\mathrm{T}$ & Sig. \\
\hline 0.563 & 0.316 & 32.561 & rejected & $118-1$ & Recruitment & 0.375 & 0.052 & 11.253 & 0.000 \\
\hline
\end{tabular}

Based on table (3), the calculated $\mathrm{f}$ value is 32.561 . It was found that the coefficient of determination is 0.316 . That means that the $31.6 \%$ of the variation in the organizational commitment are attributed to the recruitment strategies. It was found that an increase of one unit in the recruitment strategies shall lead to the increase of the organizational commitment by $(0.375)$ unit. It was found that the independent variable has a significant impact on the dependent variable. That means that the recruitment strategies have a significant impact on the organizational commitment. That is because the calculated t value is (11.253) which is a statistically significant value. Thus, the null first sub-hypothesis shall be rejected and the alternative hypothesis shall be accepted. Thus: There is significant impact at $(\alpha \leq 0.05)$ level of the strategies human resource management (employment) on organizational commitment of Jordanian Islamic banks.

H0.1.2: There is no significant impact at $(\alpha \leq 0.05)$ level of the strategies human resource management (training) on organizational commitment of Jordanian Islamic banks.

Table 4. The impact of the training strategies on the organizational commitment in Jordanian Islamic banks

\begin{tabular}{|c|c|c|c|c|c|c|c|c|c|}
\hline $\begin{array}{l}\text { Correlation } \\
\text { coefficient } \\
\text { (R) }\end{array}$ & $\begin{array}{l}\text { The coefficient of } \\
\text { determination } R 2\end{array}$ & $\begin{array}{c}\text { Calculated } \\
\text { F value }\end{array}$ & Result & $d f$. & $\begin{array}{l}\text { Regression } \\
\text { coefficient }\end{array}$ & & & & \\
\hline & & & & & $\begin{array}{c}\text { Independent } \\
\text { variable }\end{array}$ & $\beta$ & $\begin{array}{c}\text { standard } \\
\text { error }\end{array}$ & $\mathrm{T}$ & Sig. \\
\hline 0.465 & 0.216 & 25.698 & rejected & $118-1$ & Training & 0.299 & 0.045 & 8.253 & 0.000 \\
\hline
\end{tabular}

Based on table (4), the calculated $\mathrm{f}$ value is 25.698 . It was found that the coefficient of determination is 0.216 . That means that the $21.6 \%$ of the variation in the organizational commitment are attributed to the training strategies. It was found that an increase of one unit in the training strategies shall lead to the increase of the organizational commitment by 0.299 unit. It was found that the independent variable has a significant impact on the dependent variable. That means that the training strategies has a significant impact on the organizational commitment. That is because the calculated $t$ value is 8.253 which is a statistically significant value. Thus, the null second sub-hypothesis shall be rejected and the alternative hypothesis shall be accepted. There is significant impact at $(\alpha \leq 0.05)$ level of the strategies human resource management (training) on organizational commitment of Jordanian Islamic banks.

H0.1.3: There is no significant impact at $(\alpha \leq 0.05)$ level of the strategies human resource management (compensation) on organizational commitment of Jordanian Islamic banks. 
Table 5. The impact of the compensation strategies on the organizational commitment in Jordanian Islamic banks

\begin{tabular}{|c|c|c|c|c|c|c|c|c|c|}
\hline $\begin{array}{l}\text { Correlation } \\
\text { coefficient } \\
\text { (R) }\end{array}$ & $\begin{array}{l}\text { The coefficient of } \\
\text { determination } R 2\end{array}$ & $\begin{array}{c}\text { Calculated } F \\
\text { value }\end{array}$ & Result & $d f$. & $\begin{array}{l}\text { Regression } \\
\text { coefficient }\end{array}$ & & & & \\
\hline & & & & & $\begin{array}{c}\text { Independent } \\
\text { variable }\end{array}$ & $\beta$ & $\begin{array}{l}\text { standard } \\
\text { error }\end{array}$ & $\mathrm{T}$ & Sig. \\
\hline 0.638 & 0.407 & 37.587 & Rejected & $118-1$ & $\begin{array}{c}\text { compensation } \\
\text { strategies }\end{array}$ & 0.398 & 0.059 & 14.592 & 0.000 \\
\hline
\end{tabular}

Based on table (5), the calculated f value is 37.587. It was found that the coefficient of determination is 0.407 . That means that the $40.7 \%$ of the variation in the organizational commitment are attributed to the compensation strategies. It was found that an increase of one unit in the compensation strategies shall lead to the increase of the organizational commitment by 0.299 unit. It was found that the independent variable has a significant impact on the dependent variable. That means that the compensation strategies has a significant impact on the organizational commitment. That is because the calculated $t$ value is 8.253 which is a statistically significant value. Thus, the null third sub-hypothesis shall be rejected and the alternative hypothesis shall be accepted. Thus, There is significant impact at $(\alpha \leq 0.05)$ level of the strategies human resource management (compensation) on organizational commitment of Jordanian Islamic banks.

H0.1.4: There is no significant impact at $(\alpha \leq 0.05)$ level of the strategies human resource management (performance management) on organizational commitment of Jordanian Islamic banks..

Table 6. The impact of the performance management strategies on the organizational commitment in Jordanian Islamic banks

\begin{tabular}{|c|c|c|c|c|c|c|c|c|c|}
\hline $\begin{array}{l}\text { Correlation } \\
\text { coefficient } \\
\text { (R) }\end{array}$ & $\begin{array}{l}\text { The coefficient of } \\
\text { determination } R 2\end{array}$ & $\begin{array}{c}\text { Calculated } \\
\text { F value }\end{array}$ & Result & $d f$. & $\begin{array}{l}\text { Regression } \\
\text { coefficient }\end{array}$ & & & & \\
\hline & & & & & $\begin{array}{c}\text { Independent } \\
\text { variable }\end{array}$ & $\beta$ & $\begin{array}{l}\text { standard } \\
\text { error }\end{array}$ & $\mathrm{T}$ & Sig. \\
\hline 0.695 & 0.483 & 51.324 & Rejected & $118-1$ & $\begin{array}{l}\text { performance } \\
\text { management }\end{array}$ & 0.521 & 0.045 & 18.537 & 0.000 \\
\hline
\end{tabular}

Based on table (6), the calculated $\mathrm{f}$ value is 51.324. It was found that the coefficient of determination is 0.483 . That means that the $48.3 \%$ of the variation in the organizational commitment are attributed to the performance management strategies. It was found that an increase of one unit in the performance management strategies shall lead to the increase of the organizational commitment by (0.521) unit. It was found that the independent variable has a significant impact on the dependent variable. That means that the performance management strategies have a significant impact on the organizational commitment. That is because the calculated $t$ value is( 18.537) which is a statistically significant value. Thus, the null fourth sub-hypothesis shall be rejected and the alternative hypothesis shall be accepted. Thus, there is significant impact at $(\alpha \leq 0.05)$ level of the strategies human resource management (performance management) on organizational commitment of Jordanian Islamic banks.

\section{Conclusion}

\subsection{The Researchers Concluded the Following}

- The strategies human resources management in Jordanian Islamic banks is high.

- The organizational commitment level in Jordanian Islamic banks is high. 
The strategies human resources management jointly has a statistically significant impact -at the statistical significance level of $(\alpha \leq 0.05)$ - on the dimensions of organizational commitment jointly in Jordanian Islamic banks. The latter strategies are represented by (recruitment, training, compensation, and performance management strategies).

The recruitment strategies has a statistically significant impact -at the statistical significance level of $(\alpha \leq 0.05)$ - on the employees' organizational commitment in Jordanian Islamic banks.

- The training strategies has a statistically significant impact -at the statistical significance level of $(\alpha \leq 0.05)$ - on the employees' organizational commitment in Jordanian Islamic banks.

The compensation strategies has a statistically significant impact -at the statistical significance level of $(\alpha \leq 0.05)$ - on the employees' organizational commitment in Jordanian Islamic banks.

The performance management strategies has a statistically significant impact -at the statistical significance level of $(\alpha \leq 0.05)$ - on the employees' organizational commitment in Jordanian Islamic banks.

\subsection{Recommendations}

\section{The researchers recommend}

Developing the strategies of the human resources management in a manner that is consistent with the external environment of the organization.

Investing in the human capital and developing employees' skills. That requires identifying the training needs of employees

- Establishing a connection between the career path and the training path

- Developing the system of compensations and incentives.

- Improving the internal environment of organizations and developing the code of ethics of the organization.

\section{References}

Adeoye, A. O. (2014). The Influence of Compensation Management on Employees Leadership Role in Insurance Sector: Nigeria Experience. Mediterranean Journal of Social Sciences, 5(27), 342-352. https://doi.org/10.5901/mjss.2014.v5n27p342

Mutti-Assaf, A., Sawalhah, A. \& Al-Tarawneh, H. (2013). The process of continuous development (improvement) and its effects on organizational performance in the department of lands and survey. European Scientific Journal, 9(13).

Al-sawalhah, A. A., Al-Raggad, M. A. \& Aladwan, A. M. (2015). Impact of Transformational Leadership in Reducing Employees Resistance to Organizational Change. International Journal of Business and Social Science, 6(12).

AlShawabkeh, R.O. \& Alsawalhah A.A. (2019). Effects of Training Strategies on Employees Performance: A Practical Study in Ammans Municipality \Jordan. International Journal of Business and Social Science, 10(6), 84-88. https://doi.org/10.30845/ijbss.v10n6p10

Assaf, D. A. M. \& Alswalha, D. A. (2013). Environmental Impacts of Working Conditions in paint factories workers in the Hashemite Kingdom of Jordan (Field study). European Scientific Journal, 9(8).

Assaf, A (2017). Human resource information system and their impact on the effectiveness of organizational change management-apple. International Journal of Advanced Research, 5(3), 2318-2325. https://doi.org/10.21474/IJAR01/3758

Baird, L. \& Meshoulam, I. (1988). Managing Two Fits of Strategic Human Resource Management. Academy of Management Review, 13(1), 116 - 128. https://doi.org/10.5465/amr.1988.4306802

Dixit, V. \& Bhati, M. (2012). A Study about Employee Commitment and its impact on Sustained Productivity in Indian Auto-Component Industry. European Journal of Business and Social Sciences, 1(6), $34-51$.

Faloye, D. O. (2014). Organizational commitment and turnover intentions: Evidence from Nigerian paramilitary organization. International Journal of Business \& Economic Development, 2(3), 23-34.

Foot, M. \& Hook, C. (2009). Introducing Human Resource Management. Harlow: Financial Times Prentice.

Khashman, A (2019). The main resource of diversity and its effects on the quality of work life of human resouces. International Journal of Advanced Research, 5(3), 2303-2317. https://doi.org/10.21474/IJAR01/3757 
Mahal, P. K. (2012). HR practices as determinants of organizational commitment and employee retention. IUP Journal of Management Research, 11(4), 37-53.

Messner, W. (2013). Effect of organizational culture on employee commitment in the Indian IT services sourcing industry. Journal of Indian Business Research, 5(2), 76-100. https://doi.org/10.1108/17554191311320764

Onwuka,E \& Onwuchekwa, F. (2018). Compensation Management and Organizational Performance a Study of Selected Pharmaceutical Companies in Awka, Anambra State. Journal of Business and Management, 20(9).

Qaisar, M.U, Rehman, M.S \& Suffyan.M (2012). Exploring Effects of Organizational Commitment on Employee Performance: Implications for Human Resource Strategy. Interdisciplinary Journal of Contemporary Research in Business, 3(11), 248 - 255.

Al-Raggad, M. A. \& Alsawalhah, A. A. (2017). The Impact of the Strategies of Resistance to Change Management on the Improvement of Workers Performance (Case Study of the Jordanian Telecommunications Companies). Global Journal of Management and Business Research.

Sarker,M \& Rahman, M. (2018). Effect of Strategic Human Resources Management (SHRM) Practices on Perceived Financial Performance of Non-Governmental Organizations: Empirical Evidence from RDRS Bangladesh. European Journal of Business and Management www.iiste.org, 10(33), 99-110.

Singh, A. \& Gupta, B. (2015). Job involvement, organizational commitment, professional commitment \& team commitment. Benchmarking: An International Journal, 22(6), 1192-1211. https://doi.org/10.1108/BIJ-01-2014-0007

Ulrich, D. (1997). Measuring Human Resources: An Overview of Practice and Prescription for Results. Human $\begin{array}{lllll}\text { Resource } & \text { Management, } & 36(3), & 303 & -\end{array}$ https://doi.org/10.1002/(SICI)1099-050X(199723)36:3\%3C303::AID-HRM3\%3E3.0.CO;2-

Wright, P.M. \& Gardner, T.M. (2003). Theoretical and Empirical Challenges in Studying the HR Practice-Firm Performance Relationship, in the New Workplace: People Technology \& Organization, eds. D. Holman, T.D. Wall, C. Clegg, P. Sparrow and A. Howard, Sussex, UK : Wiley.

\section{Copyrights}

Copyright for this article is retained by the author(s), with first publication rights granted to the journal.

This is an open-access article distributed under the terms and conditions of the Creative Commons Attribution license (http://creativecommons.org/licenses/by/3.0/). 